\title{
Запасы азота и углерода в почвах Терско-Кумской низменности
}

\author{
Т. А. Асварова, Г.Н. Гасанов, К. М. Гаджиев, Р. Р. Баширов, К. Б. Гимбатова, \\ А. С. Абдулаева, 3.Н. Ахмедова, Ш. К. Салихов $\bowtie$ Ж. О. Кичева \\ Прикаспийский институт биологических ресурсов \\ Дагестанского федерального исследовательского иентра РАН, Российская Федерация, \\ (367000, г. Махачкала, ул. М. Гаджиева, 45)
}

\begin{abstract}
Аннотация: Цель - определить концентрации и запасы азота, углерода в светло-каштановых, лугово-каштановых типах почв и солончаке типичном под различными растительными ассоциациями пастбищных фитоценозов в заповедных условиях Терско-Кумской низменности.

Maтериалы и методы. Применение фотометрического метода «индофеноловой зелени» для определения общего азота, метода Тюрина и Кононовой для гидролизуемого азота, метода по Тюрину для гумуса и расчета углерода по изучению азотного и углеродного фонда в почвах.

Результаты и обсуждения. Общий азот колеблется в пределах 0,15-0,20\%, азот легкогидролизуемый от 2,4-5,3 мг/100 г в изучаемых типах почв, что в среднем в 2,5 раза выше, чем в целинных почвах (контроль). Гумусовый горизонт лугово-каштановой почвы (5,2 т/га) под полынно-злаковой и светло-каштановой почвой $(5,0$ т/га) под эфемероидно-полынно-злаковыми ассоциациями, более обогащен азотом по сравнению с солончаком (4,3 т/га) под разнотравно-кострово-петросимониевой ассоциацией. Запасы азота и углерода в почве осенью по сравнению с весной ниже в 1,5 раза, и в 1,6-1,8 раза с контролем, что связано с увеличением продуктивности фитоценоза в заповедном режиме.

Заключение. Исследования современного состояния азотного и углеродного почвенного фонда Терско-Кумской низменности в заповедном режиме показали, что интенсивная пастбищная нагрузка, способствующая уменьшению количества видов и проективного покрытия фитоценоза, приводит к трансформации почв, ее физико-химических свойств (снижение содержания гумуса, емкости поглощения, общего и легкогидролизуемого азота и других элементов).
\end{abstract}

Ключевые слова: азот, углерод, запасы азота и углерода, заповедный режим, тип почвы, растительные ассоциации, продуктивность.

Для цитирования: Асварова Т.А., Гасанов Г.Н., Гаджиев К. М., Баширов Р.Р., Гимбатова К.Б., Абдулаева А.С., Ахмедова 3.Н., Салихов Ш.К., Кичева Ж. О. Запасы азота и углерода в почвах Терско-Кумской низменности // Вестник Воронежского государственного университета. Серия: География. Геоэкология, 2021, № 3, с. 33-40, DOI: https://doi.org/10.17308/geo.2021.3/3598

\section{ВВЕДЕНИЕ}

Деградация почв естественных пастбищ Терско-Кумской низменности обусловлена как природно-климатическими условиями (гидротермические и эдафические факторы), так и антропогенными (пастбищная перегрузка).

Анализ экспериментальных данных $[3,6,9,16]$ экологического состояния почв и фитоценозов Северо-Западного Прикаспия показывает, что в результате антропогенной нагрузки происходит изменение физико-химических свойств почвы, снижение питательных веществ и плодородия.
Актуальность настоящей статьи связана с недостаточной изученностью потенциала концентрации, запасов азота и углерода в почвах, количественных показателей возможной продуктивности почв в заповедном режиме и на деградированных естественных пастбищах Терско-Кумской низменности.

Цель исследований - изучение концентрации, запасов азота и углерода в основных типах почв под различными растительными ассоциациями пастбищных фитоценозов в заповедных условиях Терско-Кумской низменности.

(C) Асварова Т.А., Гасанов Г.Н., Гаджиев К.М., Баширов Р.Р., Гимбатова К.Б., Абдулаева А.С., Ахмедова 3. Н., Салихов Ш.К., Кичева Ж. О., 2021

\ Салихов Шамиль Курамагомедович, e-mail: salichov72@mail.ru

(c) (i) Контент доступен под лицензией Creative Commons Attribution 4.0 License.

Вестник ВГУ, Серия: География. Геоэкология, 2021, № 3, 33-40 


\section{МАТЕРИАЛ И МЕТОДЫ}

Исследования по изучению азотного фонда Терско-Кумской низменности проведены на участках Кочубейской биосферной станции Прикаспийского института биологических ресурсов ДФИЦ РАН (КБС ПИБР ДФИЦ РАН) в заповедном режиме (без антропогенного воздействия) на экспериментальных площадках трех типов почв: солончак, светло-каштановая, лугово-каштановая, огороженных железной сеткой, размером 10 х 10 м. В качестве фона (контроль) использовалась территория вне огороженных площадок.

Географические координаты почв: светло-каштановой солонцеватой $-44^{\circ} 40^{\prime}$ с. ш., $46^{\circ} 24^{\prime}$ в. д.; лугово-каштановой $-44^{\circ} 40^{\prime}$ с. ш., $46^{\circ} 24^{\prime}$ в. д., солончака типичного $44^{\circ} 40^{\prime}$ с.ш., $46^{\circ} 24^{\prime}$.

Определение концентрации и запасов азота и углерода в почвах проводилось весной (март-апрель) и конец лета - начало осени (август-сентябрь).

Общий азот в почве установлен фотометрическим методом «индофеноловой зелени» по методу ЦИНАО (ГОСТ 26483-85), легкогидролизуемый (л. г.) азот в почвах методом Тюрина и Кононовой, гумуса и расчет углерода по методу Тюрина в модификации ЦИНАО (ГОСТ 26213-91) [2, 14].

Запасы азота и углерода в почвенном слое (0-60 см) вычисляли в т/га по формуле:

$$
Q=m \times h \times d,
$$

где $Q$ - запасы элемента (т/га) для почвенного слоя $h ; m$ - содержание элемента, $\% ; h$ - мощность почвенного слоя (см); $d$ - плотность почвы, г/ $/ \mathrm{cm}^{3}$. Статистическая обработка данных проводилась с помощью пакетов Statistica и Excel.

\section{РЕЗУЛЬТАТЫ И ИХ ОБСУЖДЕНИЕ}

Высокая пастбищная нагрузка полупустыни Терско-Кумской низменности обусловили изменения качественного и количественного состава фитоценозов и его важных составляющих - флористического состава, продуктивности. Растительный покров полупустыни характеризуется ксерофитностью, изреженностью и комплексностью.

Фитоценозы исследованных участков представлены эфемероидно-полынно-мятликовые, разнотравно-костровые злаково-полынные и другими растительными ассоциациями.

Виды растений, встречаемых на экспериментальных участках в 2011-2018 годах: семейство Poáceae - Poa bulbosa L., Bromus squarrosus L.), Anisantha tectorum L. Nevski, Hordeum leporinum Link, Eragrostic minor Host, Eremopyrom triticeum (Gaerth) Nevski.; Asteráceae - Artemisia lercheana Web.ex Stechm., Artemisia taurica Willd.; Brassicáceae - Alyssum desertorum Stapf.; Chenopodiáceae - Salsola iberica Sennenet $\mathrm{Pau}$, Ceratocarpus arenarius L.; Caryophyllaceae Herniaria incana L., Silene conica L.

В литературе имеется достаточное количество данных о содержании азота, его запасов в почвах засушливых полупустынных зон Юга России.

Так, согласно исследованиям $[1,10,11]$ запасы азота в почве и подстилке степных экосистем Северного Прикаспия составляет 11,78 т/га, и в слое 0-5 см лугово-каштановых почв 5,99 т/га.

Содержание азота в каштановых почвах засушливой территории Таманского полуострова составляет до $0,2 \%$ и гумуса $2,0-2,2 \%[4,12]$. В светло-каштановых почвах Ростовской, Волгоградской областей, Ставропольском крае количество общего азота колеблется от 0,1 до $0,24 \%$, $\mathrm{N}$ л.г. от 25 до 35 мг/кг $[5,7,8,17]$.

В светло-каштановых почвах Дагестана содержание общего и $\mathrm{N}$ л.г. в среднем составило соответственно 0,07-0,17\% и 3-4 мг/100 г почвы $[3,6,9]$.

Группа почв по насыщенности гидролизуемым азотом при рН выше 6 (метод Тюрина и Кононовой), дифференцируется на низкие - 7, средние 7-10 и высокие 10 мг/100 г почвы [13]. Почвы Терско-Кумской низменности по содержанию $\mathrm{N}$ л.г. относятся к почвам с низким уровнем обеспеченности. Колебания $\mathrm{N}$ л.г. составляют от 3,5 до 4,5 мг/100г почвы, что является одной из причин их деградации.

Содержание общего азота в почвенном слое 0-20 см в связи с низким содержанием гумуса незначительное, и с глубиной 20-40 и 40-60 см его количество снижается соответственно в 1,7 и 2,0 раза. Содержание общего азота в светло-каштановых, лугово-каштановых почвах и солончаке типичном весной в среднем составляет соответственно $0,18 \%$; $0,2 \%$ и $0,15 \%$, легкогидролизуемого азота 4,$3 ; 4,5$ и 3,8 мг $/ 100$ г (2,3-2,6\% от общего азота), запасы азота 4,3; 4,7 и 3,4 т/га, весной), осенью показатели азота (2,1-2,5\% от общего азота) и его запасы снижаются на фоне низкого содержания гумуса. Изученные типы почв отличаются низкой величиной почвенно-поглощающего комплекса (15-30мг-экв/100г), илистой фракцией, $\mathrm{pH} 7,3-7,8$, засушливым весенним и раннелетним периодами, что отражается на накоплении азота в почвах (рис. 1).

Выявлено, что содержание $\mathrm{N}$ л.г. колебалось от 2,4 до 5,0 мг/100 г в изученных типах почв в 20112013 годы и согласно полученным данным содержания $\mathrm{N}$ л.г. по Тюрину-Кононовой составляло $<4,1$ мг/100 г и выше 5,0 мг/100 г [13]. Изученные типы почв имеют низкую степень обеспеченности азотом. 


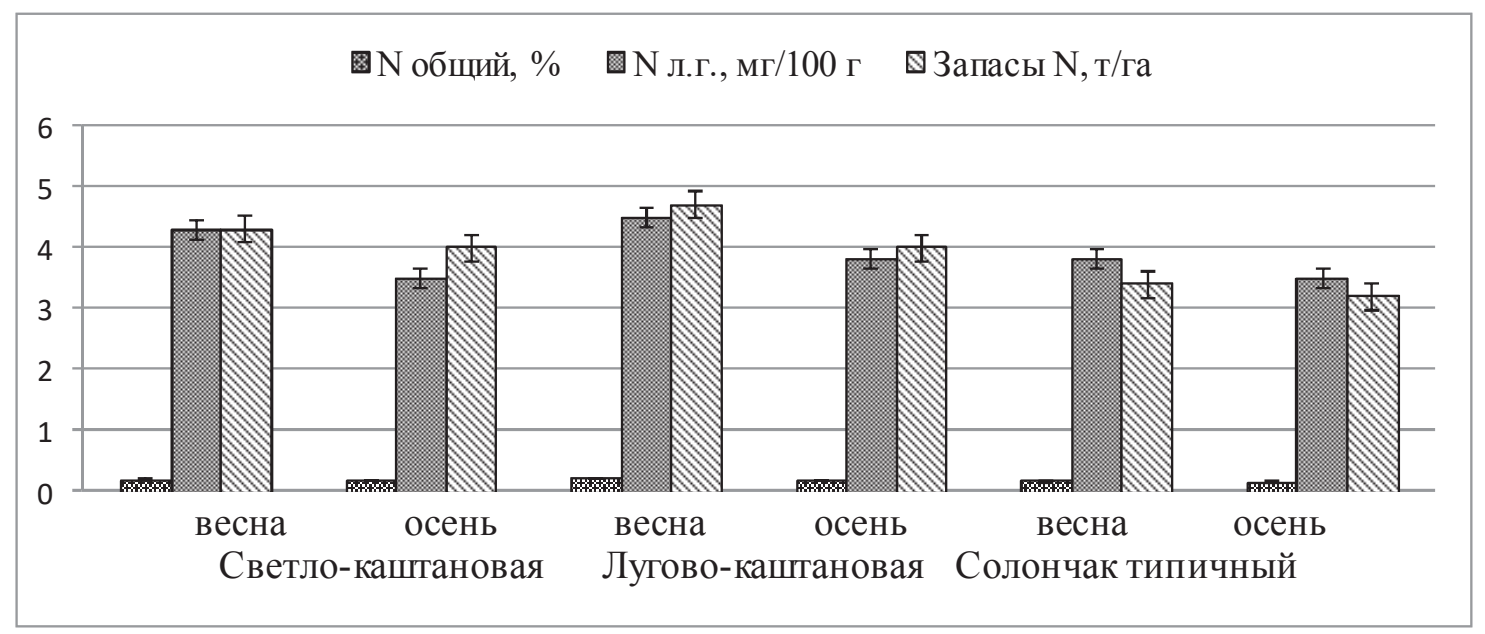

Puc. 1. Концентрации общего и легкогидролизуемого азота и его запасов в горизонте 0-20см почв Терско-Кумской низменности за 2011-2018 годы

[Fig. 1. Concentrations of total and easily hydrolyzable nitrogen and its reserves in the $0-20 \mathrm{~cm}$ horizon of the soils of the Terek-Kuma lowland for 2011-2018]

Содержание общего азота в изученных типах почв в 2011 году колебалось от 0,19 до 0,22\% весной и осенью от 0,14 до $0,18 \%$. В 2012 году показатели несколько изменились - от 0,29 до $0,37 \%$ весной и от 0,2 до $0,32 \%$ осенью, а в 2013 году соответственно от 0,05 до $0,07 \%$ и от 0,04 до $0,09 \%$. Содержание азота в почвах 2012 года выше 1,5-1,7 раза по сравнению с 2011 годом и 5-6 раз выше, чем в 2013 году. Величины соотношения C:N в годы исследований 2011-2013 годы различаются существенно. Запасы азота составляют для луго- во-каштановой почвы (5,2 т/га) под полынно-злаковой и для светло-каштановой почвы $(5,0$ т/га) под эфемероидно-полынно-злаковой. Данные почвы более обогащены азотом по сравнению с солончаком типичным (4,3 т/га) под разнотравно-кострово-петросимониевой ассоциациями.

Выявлено различие в состоянии фитоценозов в годы исследований 2011-2013 гг. не только по качественному признаку, но и количественному что влияет на запасы азота и углерода в светло-каштановых почвах (рис. 2).

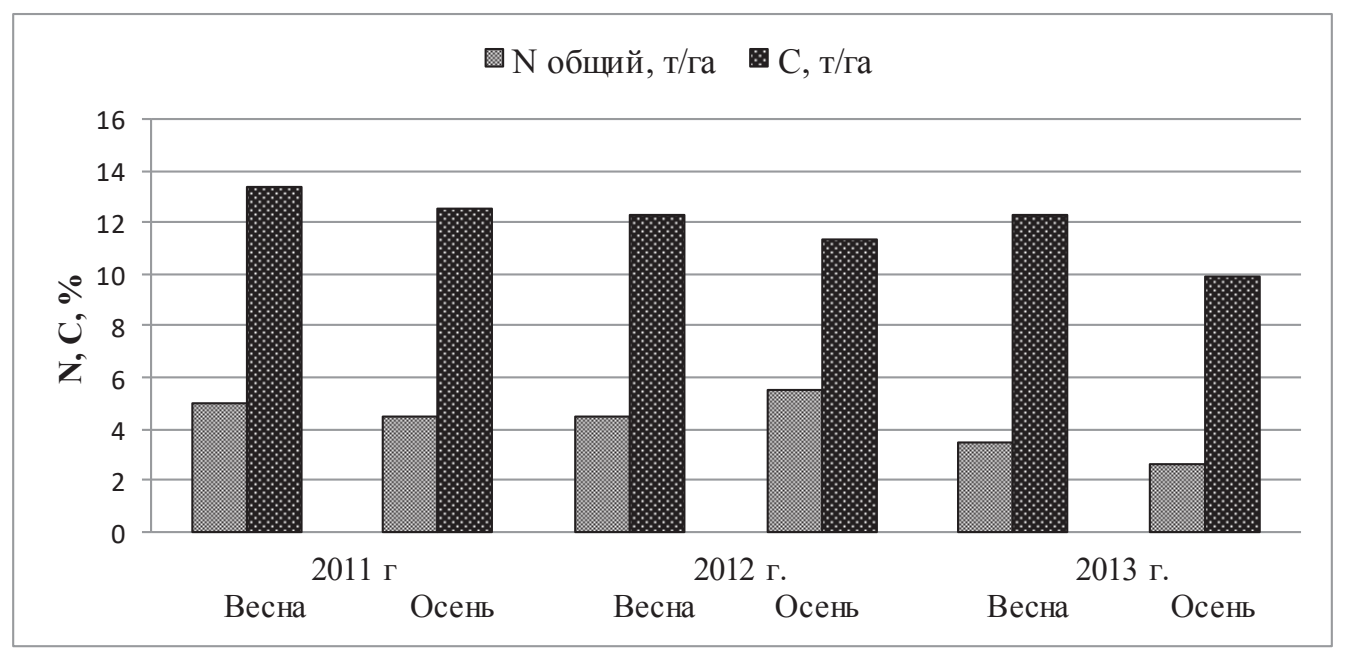

Puc. 2. Запасы азота и углерода в светло-каштановых почвах (2011-2013 гг.) (заповедный режим)

[Fig. 2. Nitrogen and carbon reserves in light chestnut soils (2011-2013) (protected regime)]

Установлено, что запасы азота в почвенном слое 0-20 см по сезонам года (весна, осень) - показатель накопления азота фитоценозом.

Колебания запасов азота в почвах 2011-2013 годов обусловлены климатическими параметрами. Так, запасы азота в почве осенью находятся в обрат- ной зависимости от весенней урожайности эфемероидов и эфемеров. При интеграле увлажненности до 30,0 весной 2011 года урожайность составила до 15,7 ц/га. Увеличение интеграла увлажненности за июнь-август 2012 года до 204,0 урожайность повысилась до 6,96 т/га. При этом содержание азота 
в почве после усвоения его фитоценозом снижалась. Так, значения запасов азота осенью 2011 года составляла в среднем 4 т/га, а весной 2012 года до 4,5 т/га и далее снижение запаса азота в почвах 2013 года до 3,2 т/га после осени урожайного 2012 года. Запасы азота в почвах 2011-2013 годов связаны с цикличностью климатических условий, проявляющихся в динамике продуктивности фитоценоза.
Запасы азота светло-каштановой почвы к августу-сентябрю (2011 и 2013) уменьшались посравнениюс апрелем-маем. Возможно, этосвязано с высокими температурами воздуха $\left(18^{\circ} \mathrm{C}\right)$ в августе и небольшим количеством осадков (25 мм), по сравнению с показателями температуры $\left(13,8^{\circ} \mathrm{C}\right.$ и обильных осадков (85 мм) весной (рис. 3).

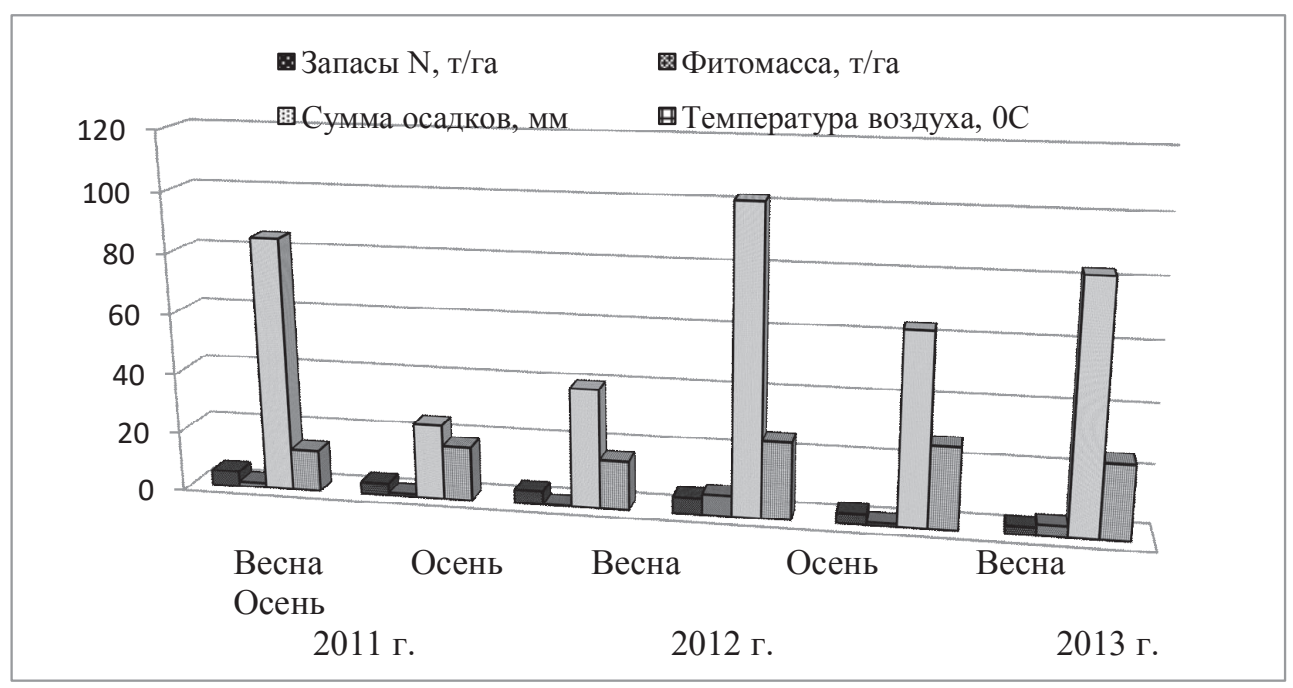

Puc. 3. Запасы азота в слое 0-20 см светло-каштановой почвы, урожайности, температуры воздуха и количеству осадков за 2011-2013 гг. КБС (заповедный режим)

[Fig. 3. Nitrogen reserves in the $0-20 \mathrm{~cm}$ layer of light chestnut soil, productivity, air temperature and precipitation for 2011-2013. Kochubey Biosphere Station (protected regime)]

В результате расчетов получены уравнения множественной регрессии зависимости содержания азота от урожайности фитомассы светло-каштановой почвы и климатических факторов:

Весна $\mathrm{Y}=0,092+1,23 \mathrm{X}-0,001 \mathrm{X}_{2}-0,003 \mathrm{X}_{3}$. $\mathrm{r}=0,96 \mathrm{R}^{2}=0,92$

Осень $\mathrm{Y}=0,635+1,49 \mathrm{X}_{1}+0,001 \mathrm{X}_{2}-0,003 \mathrm{X}_{3}$ $\mathrm{r}=0,97 \mathrm{R}^{2}=0,93$,

где $\mathrm{r}$ - коэффициент корреляции; $\mathrm{R}^{2}$ - коэффициент детерминации; у - запасы N, т/га; $\mathrm{X}_{1}$ - урожайность воздушно-сухой фитомассы, т/га; $\mathrm{X}_{2}-$ $\sum$ осадки мм; $\mathrm{X}_{3}$ - температура воздуха, ${ }^{\circ} \mathrm{C}$

Возможна интерпретация параметров модели: весной увеличение X1 - урожайность фитомассы на 1 т/га приводит к увеличению $\mathrm{Y}$ - запасы азота в среднем на 1,23 т/га, а осенью в среднем на 1,5 т/га для светло-каштановой почвы. Установлено, что в исследуемой ситуации 92-93\% от общей вариабельности запаса азота в почвах объясняется изменением урожайности фитоценоза в результате заповедного режима (2011-2018 гг.), в которых происходит переход соединений азота в его подвижную форму.

Наши данные совпадают с данными авторов [17], которые отмечают, что в каштановых почвах Ростовской области к осени уменьшается содер36 жание азота в связи со снижением биологической активности и климатическими показателями, к осени происходит снижение $\mathrm{pH}$ почв, что вероятно связано с поступлением органического вещества.

Для растительных ассоциаций, произрастающих на светло-каштановой почве, характерно постепенное изменение флористического состава ранневесенних эфемеров и эфемероидов, проективное покрытие до 70-80\% и летне-осенних ассоциаций полыни, солянки с проективным покрытием до 50-60\%.

Установлено, что накопление азота весной происходит параллельно с увеличением количества видов и проективного покрытия растительного покрова до 70-80\% и фитомассы, уменьшение покрытия и фитомассы до 40-50\% приводит к убыванию азота на заповедных участках почв. Аналогичные данные получены авторами [15] по изменению гумуса в связи с видовым составом и запасами фитомассы.

Такое детальное изучение почвенно-климатических характеристик нестандартных показателей высокой продуктивности фитоценоза в течение 2010-2013 годов в условиях полупустыни Терско-Кумской низменности в заповедном режиме показали, что в годы с небольшой продуктивностью (2010 г.) в почве накапливается большое колиSU, Series: Geography. Geoecology, 2021, no. 3, 33-40 
чество почвенного азота, который будет доступен для использования фитоценозом весной 2011 года эфемерами и эфемероидами. Именно это обстоятельство способствовало высокому урожаю и даже сенокошению трав. Высокая продуктивность фитоценоза была впервые отмечена более чем 50 лет. Осенью 2012 года происходила смена доминантов в фитоценозе. В лидеры выходила солевыносливая и засухоустойчивая Salsola iberica. В 2012 году почвы накопили меньше N л.г. Из-за выноса его из почвы для образования большой массы Salsola iberica, чем в 2011 году (N л.г. на 9,9\%). В 2013 году содержание N л.г. существенно ниже, чем в 2011 и 2012 годах. Влияние высокого урожая Salsola iberica на азотное состояние почв проявляется в заметном его снижении в 4-10 раз (рис. 3).

При наших исследованиях постоянно происходят изменения между покрытыми растительностью участков (заповедный режим) и открытыми участками почв (контрольный участок). В заповедных условиях в почвах заметно изменяется ее азотный фонд, происходит увеличение общего и легкогидролизуемого азота по сравнению с целинной почвой (контроль). На контрольном участке с интенсивным выпасом под полупустынной растительностью запасы азота и углерода в почве ниже в 1,6-1,8 раза, чем на заповедных участках. Необходимо отметить, что наши данные значительного уменьшения запасов углерода и азота в почве, находящихся под действием выпаса скота совпадают с результатами исследований других авторов в степных экосистемах $[1,10,11]$.

Концентрация азота варьирует весьма широко в зависимости от гидротермических условий, эдафических факторов, годовой сезонности, пастбищной нагрузки. Изменения условий окружающей среды приводит к смене растительных сообществ, флористического состава, доминантов. При этом тип доминантных видов влияет на содержание азота в почвах. Светло-каштановые почвы в 2011-2012 годах, в условиях повышенного увлажнения, накапливали значительное количество азота в почвах, способствующего высокой урожайности фитоценоза.

\section{ЗАКЛЮЧЕНИЕ}

Существенной причиной антропогенных изменений почвенного покрова Терско-Кумской низменности будет интенсивная пастбищная нагрузка, приводящая к опустыниванию кормовых угодий. Антропогенная деградация ведет к трансформации почв, её физико-химических свойств (снижение гумуса, влагоемкости, емкости поглощения, общего и легкогидролизуемого азота, подвижного фосфора, обменного калия и др.).
В результате исследований концентрации и запасов азота в почвах, Терско-Кумской низменности (КБС ПИБР ДФИЦ РАН, заповедный режим) 2011-2018 гг. приведены следующие выводы:

Выявлено, что общий азот колеблется в пределах $0,15-0,2 \%$, азот легкогидролизуемый от 2,4-5,3 мг/100г в солончаке, светло-каштановой, лугово-каштановой почвах, что в среднем в 2,5 раза выше, чем на контроле. Почвы имеет низкую и среднюю степени обеспеченности.

Обнаружено, что гумусовый горизонт лугово-каштановой почвы (5,2 т/га) под полынно-злаковой и светло-каштановой почвы $(5,0$ т/га) под эфемероидно-полынно-злаковыми ассоциациями, более обогащен азотом по сравнению с солончаком (4,3 т/га) под разнотравно-кострово-петросимониевой ассоциацией.

Выявлено, что запасы азота и углерода в почве весной составляют около 5 т/га азота и 13,4 т/га углерода, а осенью запасы азота и углерода ниже в 1,5 раза, в связи с уменьшением количества видов и проективного покрытия фитоценоза до 40-50\%, a также от гидротермических условий. На контрольном участке с интенсивным выпасом запасы азота и углерода в почве ниже в 1,6-1,8 раза.

Определены уравнения множественной регрессии. Установлено, что наибольшее влияние на результат запаса азота (общей вариабельность 99,8 и $88,3 \%$ ) в почвах оказывает фактор урожайности фитомассы и климатические условия.

\section{СПИСОК ЛИТЕРАТУРЫ}

1. Абатуров Б. Д., Кулакова Н. Ю. Роль выпаса животных и степных палов в круговороте азота и зольных элементов в степных пастбищных экосистемах // Аридные экосистемы, 2010, т. 16, № 2, с. 54-64.

2. Аринушкина Е. В. Руководство по химическому анализу почв. Москва: издательство МГУ, 1970. 488 с.

3. Баламирзоев М.А., Мирзоев Э.М-Р., Аджиев А.М., Муфараджиев К.Г. Почвы Дагестана. Экологические аспекты их раиионального использования. Махачкала: Дагестанское книжное издательство, 2008. 335 с.

4. Вальков В.Ф., Штомпель Ю.А., Трубилин И.Т., Котляров Н.С., Соляник Г.М. Почвы Краснодарского края, их использование и охрана. Ростов-на-Дону: издательство Сев.-Кавк. науч. центра, 1996. 191 с.

5. Вальков В.Ф., Казеев К.Ш., Колесников С.И. Почвы Юга России. Ростов-на-Дону: Эверест, 2008. 276 с.

6. Гасанов Г.Н. Экологическое состояние и научные основы повышения плодородия засоленных и подверженных опустыниванию почв Западного Прикаспия. Москва: Наука, 2006. 263 с.

7. Дегтярева Е.Т., Жулидова А.Н. Почвы Волгоградской области. Волгоград: Нижне-Волжское книжное издательство, $1970.321 \mathrm{c}$. 
8. Дорожко Г.Р., Войсковой А.И., Голоусов Н.С., Передериева В. М., Власова О.И., Кузыченко Ю. А. Земледелие Ставрополья. Ставрополь: Агрус, 2011. 327 с.

9. Залибеков 3.Г. Опьт экологического анализа почвенного покрова Дагестана. Махачкала: Прикасп. ин-т биол. ресурсов, 1995. $140 \mathrm{c.}$

10. Кулакова Н.Ю. Распределение запасов углерода и азота в лугово-каштановых почвах Северного Прикаспия в естественных степных растительных сообществах и в лесных насаждениях // Вестник Воронежского государственного университета. Серия: География. Геоэкология, 2014, № 1, с. 47-56.

11. Кулакова Н.Ю., Абатуров Б.Д., Нухимовская Ю.Д. Элементы круговорота С и N в природных и антропогенных экосистемах полупустыни Северного Прикаспия // Аридные экосистемы, 2017, т. 23, № 1 (70), с. 17-25.

12. Лукьянов А.А. Характеристика некоторых аспектов продукционного потенциала основных почв Таманского полуострова // Политематический сетевой электронный научный журнал Кубанского государственного аграрного университета, 2015, № 112 (08), с. 334-345.

13. Практикум по агрохимии / под ред. В.Г. Минеева. Москва: МГУ, 2001. 689 с.
14. Ягодин Б.А., Дерюгин И.П., Жуков Ю.П. и др. Практикум по агрохимии. Москва: Агропромиздат, 1987. 512 с.

15. Русанов А.М., Анилова Л.В. Экологические аспекты гумусообразования и динамика гумуса целинных и пахотных черноземов Предуралья // Экология, 2009, № 6, c. 417-422.

16. Саидов А.К. Картографическая оценка опустынивания - деградации земельных ресурсов российского Прикаспия и некоторые пути их улучшения (на примере Кизлярских пастбищ республики Дагестан) // Известия высиих учебных заведений. Северо-Кавказский регион. Серия: Естественные науки, 2008, №6 (148), с. 119-121.

17. Симонович Е.И., Гончарова Л. Ю. Некоторые закономерности сезонной динамики почвенной биоты и агрохимических показателей в каштановых почвах юго-востока Ростовской области // Современные проблемы науки и образования, 2016, № 2, с. 277-282.

Конфликт интересов: Авторы декларируют отсутствие явных и потенциальных конфликтов интересов, связанных с публикацией настоящей статьи.

Поступила в редакцию 28.12.2020

Принята к публикащии 03.09.2021

\title{
Nitrogen and Carbon Reserves in Soils of the Terek-Kuma Lowland
}

\author{
T.A. Asvarova, G.N. Gasanov, K.M. Gadzhiev, R.R. Bashirov, K.B. Gimbatova, \\ A.S. Abdulaeva, Z.N. Akhmedova, Sh.K. Salikhov $₫$, Zh.O. Kicheva \\ Precaspian Institute of Biological Resources of the Daghestan Federal Research Centre \\ of the Russian Academy of Sciences, Russian Federation, \\ (45, Gadzhieva, Republic of Dagestan, Makhachkala, 367000)
}

\begin{abstract}
The purpose is to determine of nitrogen, carbon concentrations and reserves in light chestnut, meadow-chestnut soil types and typical saline under various plant associations of pasture phytocenoses in the protected conditions of the Terek-Kuma lowland.

Materials and methods. Using the photometric method "in-dianalove green" for determining total nitrogen, the method of Tyurin and Kononova for easily hydrolyzable nitrogen, by Tyurin method for humus and calculation of carbon for the study of nitrogen and carbon pool in soils.

Results and discussion. Total nitrogen ranges from $0,15-0,20 \%$, and easily hydrolyzable nitrogen ranges from $2,4-5,3 \mathrm{mg} / 100 \mathrm{~g}$ in the studied soil types, which is on average 2,5 times higher than in virgin soils (control). The humus horizon of meadow-chestnut soil $(5,2 \mathrm{t} / \mathrm{ha})$ under wormwood-cereal and light- chestnut $(5,0 \mathrm{t} / \mathrm{ha})$ under ephemeroid-wormwood-cereal compared to typical saline $(4,3 \mathrm{t} / \mathrm{ha})$ under mixed grass-firepetrosimonium associations. Nitrogen and carbon reserves in the soil in autumn compared to spring are 1,5 times lower, and 1,6-1,8 times lower compared to the control, which is associated with an increase in the productivity of the phytocenosis in the protected regime.
\end{abstract}

(C) Asvarova T.A., Gasanov G.N., Gadzhiev K.M., Bashirov R.R., Gimbatova K.B., Abdulaeva A. S., Akhmedova Z.N., Salikhov Sh. K., Kicheva Zh. O., 2021

$\square$ Shamil K. Salikhov, e-mail: salichov72@mail.ru

The content is available under Creative Commons Attribution 4.0 License. 
Conclusions. Studies of the modern state of nitrogen and carbon soil of the foundation of the Terek-Kuma lowland in protected regime showed that intensive grazing load, reducing the number of species and percent cover of phytocenosis, leads to the transformation of the soil, its physical and chemical properties (decrease in humus content, adsorption capacity, total and hydrolyzable nitrogen and other elements).

Key words: nitrogen, carbon, nitrogen and carbon reserves, protected regime, soil type, plant associations, productivity.

For citation: Asvarova T.A., Gasanov G.N., Gadzhiev K.M., Bashirov R.R., Gimbatova K.B., Abdulaeva A.S., Akhmedova Z.N., Salikhov Sh.K., Kicheva Zh.O. Nitrogen and Carbon Reserves in Soils of the Terek-Kuma Lowland. Vestnik Voronezskogo gosudarstvennogo universiteta. Seria: Geografia. Geoekologia, 2021, no. 3, pp. 33-40. (In Russ.) DOI: https://doi.org/10.17308/geo.2021.3/3598

\section{REFERENCES}

1. Abaturov B.D., Kulakova N.Yu. Rol' vypasa zhivotnykh i stepnykh palov v krugovorote azota i zol'nykh elementov $\mathrm{v}$ stepnykh pastbishchnykh ekosistemakh [The role of grazing animals and steppe burns in the cycle of nitrogen and ash elements in steppe pasture ecosystems]. Aridnye ekosistemy, 2010, vol. 16, no. 2, pp. 54-64. (In Russ.)

2. Arinushkina E. V. Rukovodstvo po khimicheskomu analizu pochv [Manual for Chemical Analysis of Soils]. Moskow: izdatel'stvo MGU, 1970. 488 p. (In Russ.)

3. Balamirzoev M.A., Mirzoev E. M-R., Adzhiev A. M., Mufaradzhiev K. G. Pochvy Dagestana. Ekologicheskie aspekty ikh ratsional'nogo ispol'zovaniya [Soils of Dagestan. Environmental aspects of their rational use]. Makhachkala: Dagestanskoe knizhnoe izdatel'stvo, 2008. 335 p. (In Russ.)

4. Val'kov V.F., Shtompel' Yu.A., Trubilin I.T., Kotlyarov N. S., Solyanik G. M. Pochvy Krasnodarskogo kraya, ikh ispol'zovanie $i$ okhrana [Soils of the Krasnodar Territory, their use and protection]. Rostov-on-Don: izdatel'stvo Sev.-Kavk. nauch. tsentra, 1996. 191 p. (In Russ.)

5. Val'kov V.F., Kazeev K. Sh., Kolesnikov S. I. Pochvy Yuga Rossii [Soils of the South of Russia]. Rostov-onDon: Everest, 2008. 276 p. (In Russ.)

6. Gasanov G. N. Ekologicheskoe sostoyanie i nauchnye osnovy povysheniya plodorodiya zasolennykh i podverzhennykh opustynivaniyu pochv Zapadnogo Prikaspiya [Ecological state and scientific basis for increasing the fertility of saline and desertified soils of the Western Caspian region]. Moskow: Nauka, 2006. 263 p. (In Russ.)

7. Degtyareva E.T., Zhulidova A.N. Pochvy Volgogradskoy oblasti [Soils of the Volgograd region]. Volgograd: Nizhne-Volzhskoe knizhnoe izdatel'stvo, 1970. 321 p. DOI: http://dx.doi.org/10.1134/s2079096117010097. (In Russ.)

8. Dorozhko G.R., Voyskovoy A.I., Golousov N.S., Perederieva V.M., Vlasova O. I., Kuzychenko Yu.A. Zemledelie Stavropol'ya [Agriculture of the Stavropol Territory]. Stavropol: Agrus, 2011. 327 p. (In Russ.)

9. Zalibekov Z. G. Opyt ekologicheskogo analiza pochvennogo pokrova Dagestana [The experience of ecological analysis of the soil cover of Dagestan]. Makhachkala: Prikasp. in-t biol. resursov, 1995. 140 p. (In Russ.)

10. Kulakova N.Yu. Raspredelenie zapasov ugleroda i azota v lugovo-kashtanovykh pochvakh Severnogo Prikaspiya $\mathrm{v}$ estestvennykh stepnykh rastitel'nykh soobshchestvakh i v lesnykh nasazhdeniyakh [Distribution of carbon and nitrogen stocks in meadow-chestnut soils of the Northern Caspian region in natural steppe plant communities and in forest plantations]. Vestnik Voronezhskogo gosudarstvennogo universiteta. Seria: Geografia. Geoekologia, 2014, no. 1, pp. 47-56. (In Russ.)

11.KulakovaN. Yu.,AbaturovB.D., NukhimovskayaYu.D. Elementy krugovorota S i N v prirodnykh i antropogennykh ekosistemakh polupustyni Severnogo Prikaspiya [Elements of the $\mathrm{C}$ and $\mathrm{N}$ cycle in natural and anthropogenic ecosystems of the semi-desert of the Northern Caspian region]. Aridnye ekosistemy, 2017, vol. 23, no. 1 (70), pp. 17-25. (In Russ.)

12. Luk'yanov A.A. Kharakteristika nekotorykh aspektov produktsionnogo potentsiala osnovnykh pochv Tamanskogo poluostrova [Characteristics of some aspects of the production potential of the main soils of the Taman Peninsula]. Politematicheskiy setevoy elektronnyy nauchnyy zhurnal Kubanskogo gosudarstvennogo agrarnogo universiteta, 2015, no. 112 (08), pp. 334-345. (In Russ.)

13. Praktikum po agrokhimii [Workshop on agrochemistry]. Pod red. V.G. Mineeva. Moskow: MGU, 2001. 689 p. (In Russ.)

14. Yagodin B.A., Deryugin I.P., Zhukov Yu.P. i dr. Praktikum po agrokhimii [Workshop on agrochemistry]. Moskow: Agropromizdat, 1987. 512 p. (In Russ.)

15. Rusanov A.M., Anilova L.V. Ekologicheskie aspekty gumusoobrazovaniya i dinamika gumusa tselinnykh i pakhotnykh chernozemov Predural'ya [Ecological aspects of humus formation and dynamics of humus of virgin and arable chernozems of the Cis-Urals]. Ekologiya, 2009, no. 6, pp. 417-422. (In Russ.)

16. Saidov A. K. Kartograficheskaya otsenka opustynivaniya - degradatsii zemel'nykh resursov rossiyskogo Prikaspiya i nekotorye puti ikh uluchsheniya (na primere Kizlyarskikh pastbishch respubliki Dagestan) [Cartographic assessment of desertification - degradation of land resources in the Russian Caspian region and some ways to improve them (on the example of the Kizlyar pastures of the Republic of Dagestan)]. Izvestiya vysshikh uchebnykh zavedeniy. Severo-Kavkazskiy region. Seriya: Estestvennye nauki, 2008, no. 6 (148), pp. 119-121. (In Russ.)

17. Simonovich E.I., Goncharova L.Yu. Nekotorye zakonomernosti sezonnoy dinamiki pochvennoy bioty i agrokhimicheskikh pokazateley v kashtanovykh pochvakh yugo-vostoka Rostovskoy oblasti [Some regularities of the seasonal dynamics of soil biota and agrochemical parameters in chestnut soils in the southeast of the Rostov region]. Sovremennye problemy nauki i obrazovaniya, 2016, no. 2, pp. 277-282. (In Russ.)

Conflict of interest: The authors declare no information of obvious and potential conflicts of interest related to the publication of this article.

Received: 28.12 .2020 Accepted: 03.09.2021 


\section{T.A. Asvarova, G.N. Gasanov, K.M. Gadzhiev, R.R. Bashirov, K.B. Gimbatova, A.S. Abdulaeva, Z.N. Akhmedova et al.}

\section{Асварова Татьяна Азимовна}

кандидат биологических наук, старший научный сотрудник Прикаспийского института биологических ресурсов Дагестанского федерального исследовательского центра РАН, г. Махачкала, Российская Федерация, ORCID: 0000-0002-5285-9250, e-mail: tatacvar@mail.ru

Гасанов Гасан Никуевич

доктор сельскохозяйственных наук, профессор, заведующий лабораторией, главный научный сотрудник Прикаспийского института биологических ресурсов Дагестанского федерального исследовательского центра PAH, г. Махачкала, Российская Федерация, ORCID: 0000-0002-6181-5196, e-mail: nikuevich@mail.ru

\section{Гаджиев Камиль Магомедович}

доктор сельскохозяйственных наук, научный сотрудник Прикаспийского института биологических ресурсов Дагестанского федерального исследовательского центра PAH, г. Махачкала, Российская Федерация, ORCID: 0000-0003-1150-9593, e-mail: kamil5555372@mail.ru

\section{Баширов Рашид Радифович}

кандидат сельскохозяйственных наук, младший научный сотрудник Прикаспийского института биологических ресурсов Дагестанского федерального исследовательского центра РАН, г. Махачкала, Российская Федерация, ORCID: 0000-0002-6331-2592, e-mail: pakduik100@mail.ru

Гимбатова Кабират Бадыровна

младший научный сотрудник Прикаспийского института биологических ресурсов Дагестанского федерального исследовательского центра РАН, г. Махачкала, Российская Федерация, ORCID: 0000-0002-7516-0901, e-mail: gimbatova1954@mail.ru

\section{Абдулаева Айшат Саидмагомедовна}

научный сотрудник Прикаспийского института биологических ресурсов Дагестанского федерального исследовательского центра РАН, г. Махачкала, Российская Федерация, ORCID: 0000-0001-9056-1909, e-mail: aischat55@mail.ru

\section{Ахмедова Заира Нажмутдиновна}

научный сотрудник Прикаспийского института биологических ресурсов Дагестанского федерального исследовательского центра РАН, г. Махачкала, Российская Федерация, ORCID: 0000-0002-7141-939X, e-mail: zairaahmedova45@gmail.com

Салихов Шамиль Курамагомедович научный сотрудник Прикаспийского института биологических ресурсов Дагестанского федерального исследовательского центра РАН, г. Махачкала, Российская Федерация, ORCID: 0000-0001-5531-3045, e-mail: salichov72@mail.ru

\section{Кичева Жамилат Омаровна}

младший научный сотрудник Прикаспийского института биологических ресурсов Дагестанского федерального исследовательского центра РАН, г. Махачкала, Российская Федерация, ORCID: 0000-0001-6286-9121, e-mail: shaich74@mail.ru
Tatyana A. Asvarova

Cand. Sci. (Biol.), senior researcher of the Precaspian Institute of Biological Resources of the Daghestan Federal Research Centre of the Russian Academy of Sciences, Makhachkala, Russian Federation, ORCID: 0000-00025285-9250, e-mail: tatacvar@mail.ru

Gasan N. Gasanov

Doc. Sci. (Agric.), professor, head of laboratory, chief researcher of the Precaspian Institute of Biological Resources of the Daghestan Federal Research Centre of the Russian Academy of Sciences, Makhachkala, Russian Federation, ORCID: 0000-0002-6181-5196,e-mail: nikuevich@ mail.ru

\section{Kamil M. Gadzhiev}

Doc. Sci. (Agric.), researcher of the Precaspian Institute of Biological Resources of the Daghestan Federal Research Centre of the Russian Academy of Sciences, Makhachkala, Russian Federation, ORCID: 0000-0003-1150-9593, e-mail: kamil5555372@mail.ru

\section{Rashid R. Bashirov}

Cand. Sci. (Agric.), junior researcher of the Precaspian Institute of Biological Resources of the Daghestan Federal Research Centre of the Russian Academy of Sciences, Republic of Daghestan, Makhachkala, Russian Federation, ORCID: 0000-0002-6331-2592, e-mail: pakduik100@ mail.ru

Kabirat B. Gimbatova

junior researcher of the Precaspian Institute of Biological Resources of the Daghestan Federal Research Centre of the Russian Academy of Sciences, Republic of Daghestan, Makhachkala, Russian Federation, ORCID: 0000-00027516-0901, e-mail: gimbatova1954@mail.ru

Ayshat S. Abdulaeva

researcher Precaspian Institute of Biological Resources of the Daghestan Federal Research Centre of the Russian Academy of Sciences, Russian Federation, ORCID: 00000001-9056-1909, e-mail: aischat55@mail.ru

\section{Zaira N. Akhmedova}

researcher Precaspian Institute of Biological Resources of the Daghestan Federal Research Centre of the Russian Academy of Sciences, Makhachkala, Russian Federation, ORCID: 0000-0002-7141-939X, e-mail: zairaahmedova45@gmail.com

Shamil K. Salikhov

researcher Precaspian Institute of Biological Resources of the Daghestan Federal Research Centre of the Russian Academy of Sciences, Makhachkala, Russian Federation, ORCID: 0000-0001-5531-3045, e-mail: salichov72@mail.ru

\section{Jamilat O. Kicheva}

junior researcher of the Precaspian Institute of Biological Resources of the Daghestan Federal Research Centre of the Russian Academy of Sciences, Makhachkala, Russian Federation, ORCID: 0000-0002-7516-0901, e-mail: shaich74@mail.ru 